\title{
Optimalisasi Peran Badan Usaha Milik Negara (BUMN) pada Era Masyarakat Ekonomi Asean (MEA)
}

\author{
Isis Ikhwansyah, An-an Chandrawulan dan Prita Amalia
}

DATA NASKAH:

Masuk: 16 Februari 2017

Diterima: 11 Juli 2018

Terbit: 31 Desember 2018

KORESPONDEN PENULIS:

Fakultas Hukum Universitas

Padjadjaran

Jalan Dipati Ukur No. 35 Bandung

e-mail: ikhwansyahisis@gmail.com,

ananchandrawulan@yahoo.com,

prita.amalia@unpad.ac.id

\begin{abstract}
ASEAN Economic Community (AEC) which came into effect since 2015 requires the creativity of the Indonesian society in competing with other ASEAN countries. One of the necessary strategies in dealing with AEC is to optimize the role of the State-Owned Enterprises (BUMN). With regards to the implementation of the $\mathrm{AEC}$, it is important to provide adequate regulation in order to ensure legal certainty for BUMN. The main purpose of this research is to discover form of national regulation that can maximize business opportunity for BUMN in AEC era. It is found that the existing regulations have not yet given business opportunity for BUMN in AEC era. The existing regulations are contradictory one to another especially relating to the status of the state finance inserted as capital into BUMN. In addition, the Constitutional Court decision Number 48/PUU-XI/2013 maintained that the capital inserted into BUMN is considered as part of the state finance. Therefore, this brings about fundamental impact on future cases since the nature of the Constitutional Court decision is erga omnes.

Keywords: State-Owned Enterprises, Legal Entity, ASEAN Economic Community.
\end{abstract}

\begin{abstract}
ABSTRAK
Masyarakat Ekonomi Asean (MEA) 2015 secara tidak langsung menuntut kreativitas masyarakat Indonesia agar mampu bersaing dengan negara-negara anggota ASEAN lainnya. Salah satu langkah yang dapat ditempuh Indonesia dalam menghadapi MEA adalah dengan melakukan optimalisasi terhadap peran Badan Usaha Milik Negara (BUMN). Dalam rangka pelaksanaan MEA, peran BUMN tentunya dirasakan sangat penting bagi negara. Optimalisasi peran BUMN khususnya dalam pelaksanaan MEA perlu didukung oleh adanya regulasi yang memberikan kepastian hukum dan memberikan peluang bagi BUMN untuk dapat memaksimalkan perannya. Tujuan dilakukannya penelitian ini menganalisis dukungan regulasi hukum nasional dalam memberikan peluang bisnis bagi BUMN pada era keterbukaan Masyarakat Ekonomi ASEAN. Metode yang
\end{abstract}


digunakan dalam penelitian ini adalah berupa metode penelitian yuridis normatif. Hasil penelitian dan analisis menunjukan bahwa regulasi hukum nasional belum mampu memberikan dukungan bagi optimalisasi peran BUMN dalam era keterbukaan Masyarakat Ekonomi ASEAN. Hal ini disebabkan adanya pertentangan pengaturan terkait keuangan negara yang berasal dari APBN yang disertakan sebagai modal pada BUMN. Putusan Mahkamah Konstitusi (MK) Nomor 48/PUU-XI/2013 mepertahankan pandangan bahwa modal yang disertakan dalam BUMN merupakan bagian dari keuangan negara. Putusan MK ini memiliki dampak yang luas bagi semua perkara yang terjadi di kemudian hari karena putusan Mahkamah Konstitusi bersifat erga omnes.

Kata Kunci: BUMN, Badan Hukum, Masyarakat Ekonomi ASEAN

\section{PENDAHULUAN}

Tahun 2015 dideklarasikan sebagai permulaan Masyarakat Ekonomi ASEAN (selanjutnya disingkat MEA atau ASEAN Economic Community disingkat AEC). Dengan MEA 2015 secara tidak langsung masyarakat Indonesia dituntut untuk berkreativitas lagi agar mampu bersaing dengan negara-negara Anggota ASEAN lainnya. Indonesia dan negara anggota ASEAN lainnya dalam komunitas ini telah menyepakati integrasi ekonomi di ASEAN. Hal tersebut membuka berbagai peluang sekaligus jadi batu loncatan bagi Indonesia sendiri untuk memiliki posisi tawar yang kuat dalam konstelasi politik global.

MEA 2015 akan memberikan manfaat penurunan biaya perjalanan transportasi, menurunkan secara cepat biaya telekomunikasi, meningkatkan jumlah pengguna internet, akan semakin mudah dan cepat memperoleh informasi, semakin meningkatnya investasi dan lapangan kerja. Kesemua aktivitas tersebut tentunya perlu adanya pengaturan yang memberikan adanya kepastian, termasuk kepastian hukum dari negara yang terlibat di dalamnya.
Berdasarkan hasil penelitian tim survei ASEAN yang dilakukan LIPI pada Mei 2015 lalu, terdapat beberapa hal yang menunjukkan ketidaksiapan Indonesia dalam menyambut MEA. Pertama, berbagai kegiatan yang dilakukan kementerian dan lembaga pemerintah cenderung sektoral dan tidak selaras antara pusat dan daerah. Hal ini dapat dilihat dari pembentukan ASEAN Economic Community Center (AEC Center) yang didirikan September 2015 lalu. Manfaat pembentukan AEC ini tidak maksimal dirasakan oleh masyarakat. Banyak masyarakat yang tidak tahu mengenai hal ini. Padahal, tujuan pembentukan AEC terbilang positif yakni untuk memberikan edukasi, konsultasi dan advokasi, dengan harapan pelaku usaha dan industri mengetahui cara memanfaatkan MEA dan cara mengekspor hasil produksinya. Kedua, penerapan kebijakan Standar Nasional Indonesia (SNI) masih jauh dari harapan, khususnya bagi UKM terkait dengan pengajuan dan proses sertifikasi yang masih berbelit dan mahal. Penerapan SNI juga belum didukung sepenuhnya oleh infrastruktur SNI atau laboratorium uji dan personel yang memadai. Ketiga, pemerintah pusat dan daerah belum sepenuhnya menunjukkan keberpihakan kepada UKM. Padahal, menurutnya, UKM harus menjadi fokus penting dalam pelaksanaan MEA. Keempat, permasalahan terkait infrastruktur dan konektivitas yang dihadapi oleh dunia usaha dalam Priority Integration Sector (PIS) di Indonesia. Keterbatasan infrastruktur dan konektivitas ini yang mempengaruhi tingkat kemampuan daya saing produk dan jasa yang dihasilkan. Kelima, sifat pasif masyarakat Indonesia umumnya dianggap sebagai faktor utama penghambat sosialisasi MEA. Selain itu, terbatasnya tenaga penyuluh dan minimnya intensitas kegiatan penyuluhan membuat sosialisasi MEA tidak berkembang.

Dalam tulisan ini akan dikaji kesiapan dukungan regulasi yang ada di Indonesia dalam menghadapi MEA terhadap peran Badan Usaha Milik Negara (selanjutnya disingkat BUMN), karena 
BUMN merupakan wujud kiprah negara dalam lapangan bisnis. BUMN berdasarkan UndangUndang Nomor 19 Tahun 2003 tentang Badan Usaha Milik Negara (selanjutnya disingkat UU BUMN) terbagi menjadi 2 bentuk, yaitu Persero dan Perum.

Pengertian Persero dapat dilihat dalam Berdasarkan Pasal 1 ayat (2) Undang-Undang BUMN yang menyatakan:

"Perusahaan Persero, yang selanjutnya disebut Persero, adalah BUMN yang berbentuk perseroan terbatas yang modalnya terbagi dalam saham yang seluruh atau paling sedikit 51\% (lima puluh satu persen) sahamnya dimiliki oleh Negara Republik Indonesia yang tujuan utamanya mengejar keuntungan"

Menurut Pasal 11 Undang-Undang BUMN terhadap Persero berlaku segala ketentuan dan prinsip-prinsip yang berlaku bagi perseroan (saat ini tentunya dimaksudkan Perseroan Terbatas (PT) yang diatur dalam Undang-Undang Nomor 40 Tahun 2007 tentang Perseroan Terbatas, saat UndangUndang tersebut berlaku masalah PT diatur oleh Undang-Undang Nomor 1 Tahun 1995).

BUMN merupakan badan hukum dengan modal berupa kekayaan yang dipisahkan dari kekayaan negara. Di dalam praktik saat ini menjadi permasalahan terkait dengan kedudukan Persero sebagai badan usaha yang berbentuk BUMN yang di dalamnya terdapat kekayaan negara. Dengan adanya kekayaan negara yang dipisahkan ke dalam Persero tidak lantas menjadikan Persero tetap berada dalam rezim hukum publik. Dalam praktik terdapat 2 penafsiran masing-masing mengklaim berada dalam rezimnya. Penganut rezim hukum publik menganggap dalam kondisi seperti itu BUMN yang berbentuk Persero tetap tunduk pada rezim hukum publik, sebaliknya para akademisi memandang sesuai dengan argumentasinya, bahwa BUMN yang berbentuk Persero harus tunduk pada rezim hukum privat.

Saat negara terlibat dalam hukum bisnis, maka negara harus memposisikan dirinya sebagai badan hukum privat, namun silang pendapat dimulai saat kepemilikan sahamnya di BUMN masih dikategorikan sebagai kekayaan negara. Ketidakharmonisan kaedah yang berkaitan dengan "kekayaan negara yang dipisahkan" tersebut di atas, tidak kunjung berakhir. Antara lembaga yang satu dengan lembaga lainnya masing-masing menafsirkan sendiri-sendiri. Di satu pihak berpendapat bahwa "kekayaan negara yang dipisahkan" pada BUMN dipandang tunduk dan berada di bawah undangundang publik atau rezim hukum publik. Pandangan ini dikemukakan oleh sebagian aparat penegak hukum, Badan Pemeriksa Keuangan (BPK), Panitia Urusan Piutang Negara (PUPN) dengan masih menggunakan acuan undang-undang yang mengatur lembaganya. Sementara itu para akademisi sebagai pihak lainnya memandang tunduk dan berada di bawah undang-undang privat atau rezim hukum privat. Adapun yang menjadi dasar pihak akademisi, bahwa semua badan hukum seperti PT (Persero), Persero "Tbk", Yayasan, dan sebagainya. Secara tegas dan konsisten mendasarkan pada doktrin kekayaan terpisah dalam arti lepas sama sekali dari induknya semula. Dengan konsekuensi hukum bahwa aparataparat yang tunduk dan berada di bawah undangundang publik atau rezim hukum publik tidak serta merta dapat menggunakan kaedah hukum publik tersebut untuk memasuki wilayah hukum privat tersebut.

Dengan adanya perbedaan pandangan mengenai kedudukan BUMN Persero tersebut, mengakibatkan kurang optimalnya peran BUMN Persero dalam menjalankan aktivitas bisnisnya. Dalam kasus pengambilan kebijakan Direksi BUMN yang pure business dan nyatanya berdampak pada kerugian BUMN serta implikasinya terhadap berlakunya ketentuan Undang-Undang Tindak Pidana Korupsi memang telah ada contoh kasus riil-nya. Menurut Bagian Hukum Kementerian BUMN, BUMN yang bergerak di bidang perkebunan karet dan sawit di Lampung, direksinya ditetapkan telah merugikan keuangan negara yang melanggar Undang-Undang 
Tindak Pidana Korupsi. Padahal, pengambilan kebijakan yang dilakukan direksi adalah pure business yang dilandasi profesionalisme. Kerugian muncul karena dipengaruhi oleh faktor eksternal yaitu kondisi harga karet dan sawit ketika itu yang secara dramatis melambung tinggi. Oleh karena itu, hukum harus segera memberikan kepastian terhadap kedudukan BUMN Persero dalam menjalankan aktivitas bisnisnya, apakah tunduk pada rezim hukum privat atau rezim hukum publik.

Dalam rangka pelaksanaan MEA, peran BUMN tentunya dirasakan sangat penting bagi negara. Hal tersebut terkait dengan misi yang diemban oleh BUMN. Dalam rangka optimalisasi peran BUMN khususnya dalam pelaksanaan MEA, maka perlu didukung oleh adanya regulasi yang memberikan kepastian hukum dan memberikan peluang bagi BUMN untuk dapat memaksimalkan perannya.

\section{RUMUSAN MASALAH}

Bagaimana dukungan regulasi hukum nasional dalam memberikan peluang bisnis bagi BUMN pada era keterbukaan Masyarakat Ekonomi ASEAN?

\section{METODE PENELITIAN}

Penelitian ini menggunakan metode penelitian yuridis normatif, yaitu metode yang menitikberatkan penelitian terhadap data kepustakaan yang merupakan data sekunder. Data sekunder mempunyai ruang lingkup yang sangat luas, meliputi peraturan perundang-undangan, buku-buku literatur, jurnal-jurnal hukum, koran, majalah, internet sampai pada dokumen-dokumen resmi yang dikeluarkan oleh pemerintah (Soekanto dan Mamuji, 2003:23-24). Penyusunan penulisan penelitian ini bersifat deskriptif analitis, yaitu memaparkan data atau gambaran secermat mungkin mengenai objek dari permasalahan.

Teknik pengumpulan data sesuai dengan tahap penelitian di atas yaitu dengan melakukan studi dokumen terhadap instrumen-instrumen yang memiliki keterkaitan langsung dengan BUMN dan Masyarakat Ekonomi ASEAN.

Metode analisis data yang digunakan dalam penelitian ini adalah metode analisis normatif kualitatif. Analisis normatif karena penelitian ini bertolak dari peraturan perundang-undangan yang berlaku sebagai norma hukum positif. Sedangkan kualitatif yaitu tata cara penelitian yang dipusatkan untuk memperoleh data deskriptif, melalui apa yang dinyatakan oleh narasumber baik secara lisan maupun tulisan serta kenyataan yang terjadi. Penelitian kepustakaan dilaksanakan di beberapa tempat, yaitu :

1. Perpustakaan Univeritas Padjadjaran;

2. Perpustakaan Fakultas Hukum Universitas Padjadjaran

3. Kantor Kementerian BUMN

4. Kantor Kementerian Hukum dan HAM

5. Kantor Sekretariat ASEAN

\section{HASIL PENELITIAN DAN ANALISIS}

Dengan mulai berlakunya MEA, BUMN harus mampu untuk lebih mengoptimalkan sumber daya yang dimilikinya agar dapat bersaing dengan pelaku usaha lainnya baik dari dalam negeri maupun negara ASEAN lainnya. Subianta Mandala menyatakan, pengaruh lingkungan regional terhadap pembangunan hukum nasional tentu saja pada dewasa ini akan banyak berasal dari perkembangan di ASEAN, khususnya dalam kaitan dengan pembentukan Masyarakat Ekonomi ASEAN yang dimulai pada tahun 2015. Perkembangan ini jelas membutuhkan kesiapan untuk menghadapi persaingan yang cenderung semakin ketat, sehingga diperlukan berbagai upaya untuk meningkatkan efisiensi termasuk perbaikan sistem dan pranata hukum yang mampu mendukung kegiatan ekonomi dan bisnis yang semakin modern. Segala perubahan dengan berbagai implikasinya tersebut semestinya terus dipantau dengan sikap terbuka, agar dapat dicari jalan untuk lebih menyesuaikan diri dengan 
perubahan-perubahan itu tanpa merugikan kepentingan nasional.

Apabila BUMN tidak dapat mengoptimalkan segala sumber daya yang dimilikinya, maka berlaku MEA bukan merupakan sebagai peluang usaha tetapi sebagai ancaman bagi bisnis yang dijalankan oleh BUMN. Salah satu faktor yang perlu dicermati dan mempunyai pengaruh besar terhadap BUMN adalah regulasi yang mengikat bagi BUMN. Sebagai badan usaha yang dimiliki oleh negara, terdapat beberapa regulasi yang mengikat bagi BUMN dalam menjalankan aktivitas bisnisnya. Beberapa regulasi tersebut hanya mengikat bagi BUMN dan tidak mengikat bagi badan usaha milik swasta. Hal tersebut sebagai konsekuensi bahwa pemilik BUMN adalah negara.

BUMN sebagai suatu badan usaha sebenarnya memiliki undang-undang tersendiri yang khusus mengatur tentang BUMN, yaitu Undang-Undang Nomor 19 Tahun 2003 tentang BUMN. Selain undang-undang tersebut terdapat undang-undang lainnya dan juga peraturan perundang-undangan lain yang berlaku dan mengikat BUMN. Sebagai contoh Undang-Undang tentang Perseroan Terbatas berlaku bagi BUMN yang berbentuk Persero, UndangUndang Nomor 8 Tahun 1999 tentang Pasar Modal berlaku bagi BUMN yang berbentuk PT Persero Tbk, dan peraturan perundang-undangan bidang sektoral yang akan mengikat bagi BUMN yang menjalankan bisnisnya dalam bidang tersebut.

Idealnya regulasi yang mengikat bagi BUMN tersebut bersifat harmonis, dalam arti tidak bertentangan satu sama lainnya. Selain itu juga, seharusnya setiap regulasi yang mengikat BUMN dapat mendukung agar BUMN dapat optimal dalam menjalankan aktivitas bisnisnya.

Salah satu pokok permasalahan dalam praktik saat ini terkait dengan berlakunya regulasi yang mempengaruhi aktivitas BUMN adalah mengenai kekayaan BUMN. Pengaturan status kekayaan BUMN ini terdapat dalam 2 rezim masing-masing berjalan sektoral, yaitu rezim hukum korporasi dan rezim hukum keuangan negara.

Menurut rezim hukum korporasi, BUMN sebagai sebuah badan usaha yang berbadan hukum memiliki kekayaan yang terpisah dari kekayaan pemiliknya. Kekayaan BUMN berasal dari kekayaan negara yang dipisahkan. Prinsip hukum korporasi, menyatakan bahwa kekayaan yang dipisahkan pada perusahaan harus terlepas dari pemiliknya. Jadi dengan demikian seharusnya kekayaan BUMN tidak dikategorikan sebagai keuangan negara yang memiliki konsekuensi lainnya bagi BUMN. Dalam regulasi yang ada dan menganut rezim hukum korporasi, misalnya UU BUMN. Hal ini tampak dalam Pasal 1 angka 1 Undang-Undang BUMN yang menyebutkan bahwa: "Badan Usaha Milik Negara yang selanjutnya disebut BUMN, adalah badan usaha yang seluruh atau sebagian modalnya dimiliki oleh negara melalui penyertaan secara langsung yang berasal dari kekayaan negara yang dipisahkan." Selanjutnya ketentuan Pasal 4 ayat (1) Undang-Undang BUMN menyatakan bahwa: "Modal BUMN merupakan dan berasal dari kekayaan negara yang dipisahkan."

Berdasarkan kedua ketentuan dalam UndangUndang BUMN tersebut, dinyatakan secara tegas bahwa modal BUMN berasal dari kekayaan negara yang dipisahkan. Dengan demikian seharusnya apabila kekayaan negara yang dijadikan modal untuk BUMN tersebut telah dipisahkan, maka kekayaan negara tersebut menjadi kekayaan milik BUMN sebagai badan hukum yang memiliki kekayaan terpisah dari para pemiliknya. Hal tersebut juga dikuatkan dengan penjelasan Pasal 4 ayat (1) UndangUndang BUMN yang menyatakan: "Yang dimaksud dengan dipisahkan adalah pemisahan kekayaan negara dari Anggaran Pendapatan dan Belanja Negara (APBN) untuk dijadikan penyertaan modal negara pada BUMN untuk selanjutnya pembinaan dan pengelolaannya tidak lagi didasarkan pada sistem APBN. Pembinaan dan pengelolaannya didasarkan pada prinsip-prinsip perusahaan yang sehat.” 
Pengaturan dalam Undang-Undang BUMN tampak sesuai dengan pandangan rezim hukum korporasi. Pandangan berbeda dikemukakan oleh rezim hukum keuangan negara, yang pada intinya menyatakan bahwa kekayaan BUMN termasuk ke dalam keuangan negara. Pendapat tersebut dapat diketahui dalam beberapa peraturan perundanganundangan yang berlaku. Salah satu regulasi yang menganut rezim tersebut adalah Undang-Undang Nomor 17 Tahun 2003 tentang Keuangan Negara (selanjutnya disingkat UU Keuangan Negara). Dalam Pasal 1 angka 1 UU Keuangan Negara disebutkan bahwa: "Keuangan Negara adalah semua hak dan kewajiban negara yang dapat dinilai dengan uang, serta segala sesuatu baik berupa uang maupun berupa barang yang dapat dijadikan milik negara berhubung dengan pelaksanaan hak dan kewajiban tersebut."

Pada Pasal 2 Undang-Undang Keuangan Negara, yang menyatakan: "Keuangan negara sebagaimana dimaksud dalam Pasal 1 angka 1, meliputi: kekayaan negara/kekayaan daerah yang dikelola sendiri atau oleh pihak lain berupa uang, surat berharga, piutang, barang, serta hak-hak lain yang dapat dinilai dengan uang, termasuk kekayaan yang dipisahkan pada perusahaan negara/perusahaan daerah."

Berdasarkan ketentuan Undang-Undang Keuangan Negara tersebut, maka keuangan BUMN termasuk dalam lingkup keuangan negara. Demikian juga dengan kekayaan, aset dan kerugian BUMN termasuk juga dalam lingkup keuangan negara, sehingga tindakan yang merugikan BUMN dianggap juga sebagai tindakan yang merugikan negara.

Regulasi lain yang menganut rezim hukum keuangan negara, yaitu Undang-Undang Nomor 31 Tahun 1999 tentang Pemberantasan Tindak Pidana Korupsi (selanjutnya disingkat UU Tipikor). Dalam Bagian Penjelasan Umum UU Tipikor disebutkan bahwa: "Keuangan negara yang dimaksud adalah seluruh kekayaan negara dalam bentuk apapun, yang dipisahkan atau yang tidak dipisahkan, termasuk di dalamnya segala bagian kekayaan negara dan segala hak dan kewajiban yang timbul karena:
1. berada dalam penguasaan, pengurusan, dan pertanggungjawaban pejabat lembaga negara, baik di tingkat pusat maupun di daerah;

2. berada dalam penguasaan, pengurusan, dan pertanggungjawaban BUMN/Badan Usaha Milik Daerah (BUMD), yayasan, badan hukum, dan perusahaan yang menyertakan modal negara, atau perusahaan yang menyertakan modal pihak ketiga berdasarkan perjanjian dengan negara."

Berdasarkan Bagian Penjelasan Umum UU Tipikor tersebut, maka kekayaan BUMN termasuk juga dalam lingkup keuangan negara. Dengan demikian tindakan yang merugikan BUMN dianggap sebagai tindak pidana korupsi.

Dalam ketentuan Pasal 1 angka 7 UU BPK Undang-Undang Nomor 15 Tahun 2006 tentang Badan Pemeriksa Keuangan (selanjutnya disingkat UU BPK), disebutkan bahwa: "Keuangan Negara adalah semua hak dan kewajiban negara yang dapat dinilai dengan uang, serta segala sesuatu baik berupa uang maupun berupa barang yang dapat dijadikan milik negara berhubung dengan pelaksanaan hak dan kewajiban tersebut."

Berdasarkan pengertian di atas, maka tampak adanya kesamaaan pandangan dengan yang telah diberikan oleh pengertian keuangan negara sebagaimana yang terdapat dalam Undang-Undang Keuangan Negara. Dengan demikian BPK berwenang untuk melakukan pemeriksaan terhadap keuangan negara pada BUMN.

Tampak sekali dari kedua regulasi tersebut di atas adanya kontradiksi peraturan perundangundangan yang mengatur tentang BUMN khususnya mengenai kedudukan kekayaan BUMN. Dalam mengatasi permasalahan seperti ini, teori hukum harus memberikan jawaban dengan asas hukum. Adanya pertentangan antara 2 peraturan perundangundangan dalam mengatur objek masalah hukum yang sama dijawab oleh asas hukum. Apabila terdapat pertentangan pengaturan terhadap suatu masalah 
hukum, maka ketentuan yang bersifat khusus mengesampingkan ketentuan yang bersifat umum, sesuai asas lex specialis derogat legi generalis.

Pada dasarnya BUMN yang berbentuk Persero atau PT (Persero) sama sebagai PT biasa, seperti halnya PT-PT yang lain. Adapun kekhususannya berdasarkan ketentuan Undang-Undang BUMN, modal yang terbagi dalam saham itu seluruh atau paling sedikit $51 \%$ (lima puluh satu persen) dimiliki oleh negara, yang bertujuan untuk mengejar keuntungan (profit oriented). PT (Persero) adalah suatu entitas hukum mandiri, yang mempunyai persona standi in judicio. Menurut rezim hukum korporasi, kedudukan negara di sini berstatus sebagai pemegang saham, bukan sebagai negara lagi.

Hukum harus memperlakukan BUMN sama dengan PT biasa. Tidak boleh membedakan kedudukan BUMN sebagai badan hukum publik yang tunduk pada peraturan perundang-undangan yang bersifat publik dan BUMN sebagai badan hukum privat, tunduk pada ketentuan hukum privat.

Negara tidak memiliki keleluasan untuk mengeluarkan wewenang yang bersifat publik dalam pengelolaan sektor privat yang tata kelola dan tata tanggung jawabnya tunduk pada ketentuan privat. Dalam hal ini pemerintah sebagai representasi pemilik saham BUMN (Persero) diminta menyadari tanggung jawab atas risiko kepemilikan saham yang diakui sebagai kekayaan negara.

Sudah sejak awal dalam peraturan perundangundangan memperlakukan BUMN sebagai suatu unit usaha yang profit oriented. Dengan demikian, BUMN harus dapat menjalankan perusahaan itu secara profesional. Pada saat ini BUMN masih belum diberi kebebasan penuh dalam menjalankan bisnisnya secara profesional. Dengan regulasi yang ada dalam opersional BUMN yang dijalankan oleh manajemen BUMN timbul suatu keadaan dan risiko besar yang harus dipikul karena dianggap mengelola uang negara. Manajemen BUMN tidak memiliki kebebasan lazimnya dalam menjalankan suatu usaha secara profesional karena risiko apabila dalam menjalankan bisnis mendatangkan kerugian pada perusahaan dapat dianggap merugikan keuangan negara dan dijerat tindak pidana korupsi. Manajemen BUMN dalam menjalankan bisnis seharusnya memiliki keleluasaan di dalam membuat keputusan bisnis yang profesional, karena tindakannya akan terlindungi oleh doktrin Bussiness Judgement Rules.

Langkah yang telah dilakukan ke arah harmonisasi regulasi diantaranya dilakukan oleh Mahkamah Agung (MA) dengan dihasilkan pemikiran-pemikiran yang diharapkan memperjelas kedudukan BUMN. Sesuai dengan perannya Mahkamah Agung telah memberikan pemikirannya bagi para hakim di seluruh Indonesia, khususnya yang menangani perkara-perkara perdata, tak perlu lagi bingung bila menangani kasus gugatan perdata yang salah satu tergugatnya adalah BUMN atau BUMD. Dukungan yang diberikan MA melalui Rapat Kerja Nasional MA (Rakernas MA) 2010 telah memberi petunjuk kepada para hakim dalam melakukan sita jaminan atau sita eksekusi terhadap harta BUMN atau BUMD. Rakernas MA menyimpulkan bahwa harta kekayaan BUMN atau BUMD dapat disita oleh pengadilan. "Terhadap keuangan negara yang disertakan inbreng (penyertaan modal) dalam BUMN atau BUMD persero dapat disita," demikian bunyi kesimpulan yang dihasilkan oleh Bidang Perdata Umum di Balikpapan, Kalimantan Timur, tahun 2010.

Berdasarkan hasil dan kesimpulan Raker tersebut tampaknya sudah sejalan pula dengan Fatwa MA yang pernah dikeluarkan oleh MA terkait pengakuan terhadap kekayaan yang dipisahkan dari APBN pada BUMN. Artinya konsisten dalam memberikan pengakuan terhadap kekayaan negara hasil dari pemisahan dari APBN/APBD pada BUMN/BUMD tetap harus tunduk dan berlaku Undang-Undang Nomor 40 Tahun 2007 tentang Perseroan Terbatas.

Hasil Raker MA pun telah menetapkan agar tak sembarangan harta kekayaan BUMN atau BUMD yang bisa disita. Intinya, kekayaan negara yang sudah 
disertakan sebagai modal BUMN atau BUMD yang dapat disita karena kekayaan itu bukan lagi milik negara melainkan sudah menjadi harta miliki BUMN atau BUMD. "Status harta ini tunduk pada UndangUndang Nomor 40 Tahun 2007 tentang Perseroan Terbatas dan dikelola oleh perseroan berdasarkan prinsip-prinsip pengelolaan perusahaan yang sehat." Demikian kesimpulan tim perumus Raker MA Tahun 2010. Selanjutnya MA menyatakan dalam Raker, uang atau barang milik negara yang bukan penyertaan modal tetapi dikelola oleh BUMN atau BUMD tak dapat dilakukan sita jaminan atau sita eksekusi. Hal ini mengacu kepada pada Pasal 50 Undang-Undang Nomor 1 Tahun 2004 tentang Perbendaharaan Negara yang menyatakan harta kekayaan milik negara tak bisa disita oleh pengadilan. Dalam praktik penegakkan hukum pun berdasarkan pengamatan selama ini, berkembang dua penafsiran terhadap keberadaan kekayaan negara yang 'diparkir' di BUMN atau BUMD. Pandangan pertama, adalah menyamakan status BUMN atau BUMD dengan Perseroan Terbatas (PT) lainnya. Dengan demikian, kekayaan BUMN atau BUMD bisa disita oleh pengadilan. Akibatnya Menteri Keuangan (Menkeu) selaku wakil pemerintah tak bisa melakukan derden verzet (perlawanan pihak ketiga) karena yang disita pengadilan bukan lagi kekayaan milik negara, melainkan milik BUMN atau BUMD. Pandangan kedua berpendapat sebaliknya, para hakim yang menggunakan pandangan ini berpendapat kekayaan BUMN atau BUMD tak dapat disita karena beranggapan kekayaan itu adalah milik negara. Pasalnya, negara lah yang menanamkan modal (berasal dari APBN atau APBD) kepada BUMN atau BUMD. Pandangan tersebut menggunakan Pasal 50 Undang-Undang Perbendaharaan Negara sebagai dasarnya. Selain itu, para hakim yang menggunakan pandangan ini juga merujuk kepada Pasal 1 butir 11 Undang-Undang Perbendaharaan Negara. Ketentuan ini berbunyi: "Barang milik daerah adalah semua barang yang dibeli atau diperoleh atas beban APBD atau berasal dari perolehan lain yang sah."
Pada dasarnya dengan kesimpulan hasil dari Rakernas MA ini dapat menjadi pegangan bagi hakim dalam penegakkan hukum karena perbedaan dua pandangan ini sudah dapat disatukan. Berdasarkan catatan hukumonline, sita jaminan terhadap harta kekayaan BUMN sudah kerap terjadi. Salah satu contohnya adalah sita jaminan dua kapal milik PT Djakarta Lloyd (Persero) oleh majelis hakim Pengadilan Negeri Jakarta Pusat pada awal Februari 2009. Dalil pihak PT Djakarta Llyod (tergugat) yang menyatakan sita jaminan bertentangan dengan Pasal 50 Undang-Undang Perbendaharaan Negara yang melarang penyitaan aset milik negara dibantah oleh majelis hakim. Dalam pertimbangannya, majelis berpendapat harta kekayaan BUMN tidak termasuk barang milik negara. Pasalnya, BUMN sebagai badan hukum perdata keberadaannya di luar struktur organisasi lembaga negara atau pemerintah.

Upaya yang dirintis MA tampaknya di dalam praktiknya masih tidak berjalan mulus karena berdasarkan hasil penelitian di lapangan saat ditanyakan pada hakim tingkat Pengadilan Niaga menangani perkara Kepailitan BUMN, semua hakim pengadilan niaga yang diwawancara serempak berpandangan dan menyatakan apabila BUMN dimohonkan pailit, maka harus dilakukan oleh Menteri Keuangan.

Upaya MA pun semakin jauh dari harapan mendapat dukungan dalam penegakkan hukum. Selain hasil Raker tidak dijadikan acuan oleh para hakim dalam praktik penegakkan hukum di tingkat bawah, Mahkamah Konstitusi (MK) pun menolak judicial review menyangkut kekayaan BUMN yang berasal dari Kekayaan Negara yang dipisahkan.

Pada kenyataannya, tekad dan kemauan Pemerintah ini dinilai dan dipandang lain oleh beberapa pihak, yang memandang bahwa pendekatan pengertian Keuangan Negara itu bertentangan dengan Konstitusi, khususnya menyangkut kekayaan negara yang dipisahkan sebagai modal pada BUMN/BUMD. Pihak-pihak tersebut memandang bahwa campur tangan Pemerintah dan BPK RI 
terhadap BUMN/BUMD telah menyebabkan terjadinya kondisi bahwa BUMN/BUMD tidak dapat memiliki daya saing dalam menghimpun laba. Pihak tersebut cenderung mengalihkan perhatian dari peran pemerintah dan tujuan strategis dari negara dalam membentuk badan usaha, dengan mengangkat isu perolehan laba, walau pada faktanya, secara materiil BUMN sanggup menghadirkan laba yang signifikan seperti PT BRI (Persero), tbk, PT Bank Mandiri (Persero), PT BNI.

Dalam rangka menyongsong keterbukaan Masyarakat Ekonomi ASEAN dengan berbagai putusan hakim yang dipandang kurang mendukung terhadap langkah untuk menyusun regulasi hukum nasional yang dapat memberikan peluang bisnis bagi BUMN semakin jauh dari harapan. Padahal dengan adanya berbagai upaya penyamaan persepsi dapat menjadi tonggak awal untuk terciptanya penyusunan regulasi yang memberikan dukungan pada BUMN dalam berkiprah secara optimal dan profesional sebagai pelaku usaha yang akan mampu bersaing dalam era MEA.

Sebagaimana telah diuraikan di atas, upaya untuk mengembalikan pemahaman terhadap keuangan Negara pada BUMN hasil dari penyertaan APBN sebagai kekayaan BUMN sebagai PT Persero terlepas dari keuangan negara telah diperjuangkan oleh Center for Strategies Studies University of Indonesia (CCS-UI), Forum BUMN dan lembaga yang perduli BUMN, melalui upaya pengujian materi UndangUndang Keuangan Negara ini terhadap UndangUndang Dasar (UUD) 1945 dengan Perkara Nomor 48/PUU-XI/2013 tertanggal 22 Mei 2013 dan Perkara Nomor 62/PUU-X1/2013 tertanggal 17 Juni 2013. Hasilnya, oleh Mahkamah Konstitusi menolak permohonan pihak-pihak tersebut secara seluruhnya.

Sebelum perkara tersebut diputus MK, Hasan Bisri mengakui akan keberadaan dari keuangan negara yang berasal dari APBN lewat penyertaan pada BUMN, Hasan Bisri (saat itu Wakil Ketua Badan Pemeriksa Keuangan) mengatakan BUMN harus tetap menjadi bagian dari keuangan negara. Namun diakuinya agar BUMN bisa berkembang, perlu diberikan otonomi dalam pengelolaannya yaitu mengikuti kaidah-kaidah bisnis yang sehat, termasuk mengikuti ketentuan undang-undang perseroan. Kekayaan negara pada BUMN harus terpisah dari APBN agar kekayaannya dapat dikelola sesuai dengan prinsip-prinsip bisnis yang sehat dan efisien untuk sebesar-besarnya kemakmuran rakyat. Lebih lanjut dinyatakan bahwa maksud pengertian kekayaan negara yang dipisahkan pada BUMN adalah dipisah dari sistem pencatatan dan pengelolaan APBN. Walaupun demikian, keuangan yang berasal dari APBN dipisahkan dari BUMN tetap merupakan bagian dari kekayaan negara, aset negara, dan keuangan negara.

Pandangan lain dikemukakan oleh Nindyo Pramono yang menyimpulkan Undang-Undang Keuangan Negara berdampak tidak ada kepastian hukum bagi pelaksana Undang-Undang BUMN dan undang-undang terkait. Selanjutnya diungkapkan dalam kenyataannya Direksi BUMN dibayang-bayangi kekhawatiran dari keputusan bisnis yang jujur dan akuntabel, tetapi dituduh korupsi karena mengakibatkan kerugian negara. Hal ini tidak tepat jika kekayaan negara yang dipisahkan menjadi modal BUMN masih dikategorikan sebagai bagian keuangan negara seperti diatur Undang-Undang Keuangan Negara. Pengurus BUMN bukan penyelenggara negara, melainkan organ BUMN seperti halnya direksi-direksi perusahaan lainnya.

Menurut ketentuan di dalam Pasal 2 huruf g Undang-Undang Perbendaharaan Negara juga dikatakan bahwa: "Keuangan Negara sebagaimana dimaksud di dalam Pasal 1 Angka (1) tersebut meliputi: kekayaan negara/daerah yang dikelola sendiri atau oleh pihak lain berupa uang, surat berharga, piutang, barang serta hak-hak lain yang dapat dinilai dengan uang, termasuk kekayaan yang dipisahkan pada perusahaan negara/perusahaan daerah". Sementara itu Undang-Undang BUMN menegaskan bahwa PT ( Persero ) dalam melakukan kegiatan usahanya tunduk pada Undang-Undang 
Nomor 40 tahun 2007 Tentang Perseroan Terbatas. Dengan demikian segala kebijakan sektoral terkait dengan aksi korporasi atau dalam rangka business judgement yang dilakukan oleh Direksi PT (Persero) berlaku secara equal bagi semua entitas bisnis baik PT Swasta maupun PT (Persero) seperti misalnya pengaturan dan/atau penyusunan RKAP, penentuan dan/atau penunjukan auditor perseroan, pengaturan mengenai pengadaan barang dan jasa, penghapusan aset perseroan, penghapusan piutang dan sebagainya. Semua ini adalah ranah business judgement rule Perseroan.

Namun yang terjadi saat ini selalu timbul kekhawatiran dari Direksi PT (Persero) bahwa dalam membuat keputusan bisnis selalu dibayang-bayangi akan timbulnya ekses negatif terkait dengan keputusan bisnis yang dijalankan. Mereka paham sekali bahwa dalam membuat keputusan bisnis tidak ada satupun direksi yang mampu memastikan bahwa keuntungan yang diprediksikan akan diperoleh melalui perhitungan-perhitungan bisnis yang akurat, wajar dan akuntabel sesuai dengan standard operation procedure (SOP) yang telah ditetapkan, sesuai dengan prinsip kehati-hatian dan dilandasi oleh prinsip itikad baik dengan mengedepankan prinsip-prinsip good corporate governance. Keuntungan tersebut akan benarbenar atau pasti akan diperoleh sesuai dengan prediksi tersebut.

Nindyo Pramono menyatakan, berdasarkan pengamatan dan pengalamannya, tidak semua Direksi Persero paham akan yang dikemukakan di atas. Bisa dimaklumi karena tidak semuanya bahkan mayoritas tidak berlatar belakang pendidikan hukum. Walaupun ada Biro Hukum di perseroan tersebut namun tidak memahami pengetahuan tentang hukum bisnis, maka dapat dipastikan juga tidak akan memahami ketidakharmonisan beberapa kaedah hukum sebagaimana diuraikan di atas. Oleh sebab itu tidak heran jika dibaca di media-media, BUMN di Indonesia sering dibandingkan dengan BUMN negara-negara tetangga yang sangat jauh dalam pencapaian revenue-nya.
Dalam penelitian yang dilakukan penulis ke sejumlah Pengadilan Niaga di lima kota, yaitu: Medan, Semarang, Jakarta, Surabaya dan Makasar, maka berdasarkan hasil wawancara dengan praktisi hukum yang ada dengan tegas menafsirkan bahwa kekayaan BUMN merupakan kekayaan negara, bahkan hakim-hakim di Pengadilan Niaga mengatakan bahwa kekayaan BUMN itu adalah kekayaan negara. Perbedaan penafsiran ini, sebagai dampak adanya ketidakharmonisan di dalam menyikapi BUMN sebagai badan hukum yang mandiri, antara rezim hukum privat dan rezim hukum publik. Dari rezim hukum publik, ada dua undang-undang yang mengklaim bahwa kekayaan BUMN itu termasuk kekayaan negara, yakni UndangUndang Keuangan Negara dan Undang-Undang Perbendaharaan Negara. Padahal dari kacamata hukum privat, yang disebut pelaku usaha baik badan hukum publik atau privat, kalau melaksanakan bisnis harus tunduk kepada rezim hukum bisnis.

Terkait dengan perbedaan pandangan tersebut, beberapa waktu yang lalu MA telah mengeluarkan Fatwa Nomor: WKMA/Yud/20/VIII/ 2006 tanggal 16 Agustus 2006, yang pada intinya menyatakan bahwa:

1. Piutang BUMN bukan merupakan piutang negara;

2. Ketentuan Pasal 2 huruf g Undang-Undang Keuangan Negara mengenai "kekayaan yang dipisahkan pada perusahaan negara/perusahaan daerah", tidak mempunyai kekuatan mengikat secara hukum.

Upaya serius MA untuk menyatukan persepsi dalam penegakkan hukum terhadap pemahaman kekayaan yang dipisahkan dari APBN pada BUMN Persero oleh Rakernas MA 2010 sebagaimana telah dikemukakan di atas, telah menghasilkan kesimpulan dan menjadi petunjuk kepada para hakim dalam melakukan sita jaminan atau sita eksekusi terhadap harta BUMN atau BUMD. Rakernas MA menyimpulkan bahwa harta kekayaan BUMN atau BUMD dapat disita oleh pengadilan. Terhadap 
keuangan negara yang disertakan inbreng (penyertaan modal) dalam BUMN atau BUMD persero dapat disita, demikian bunyi kesimpulan yang dihasilkan oleh Bidang Perdata Umum. Namun tidak semua harta kekayaan BUMN atau BUMD yang dapat disita.

Intinya, kekayaan negara yang telah disertakan sebagai modal BUMN atau BUMD dapat disita karena kekayaan itu bukan lagi milik negara melainkan sudah menjadi harta miliki BUMN atau BUMD. Dengan demikian, status harta ini tunduk pada Undang-Undang Nomor 40 Tahun 2007 tentang Perseroan Terbatas dan dikelola oleh perseroan berdasarkan prinsip-prinsip pengelolaan perusahaan yang sehat. Pada sisi lain, uang atau barang milik negara yang bukan penyertaan modal tetapi dikelola oleh BUMN atau BUMD tidak dapat dilakukan sita jaminan atau sita eksekusi. Hal ini mengacu kepada pada Pasal 50 UndangUndang Nomor $1 \quad$ Tahun 2004 tentang Perbendaharaan Negara yang menyatakan bahwa harta kekayaan milik negara tidak bisa disita oleh pengadilan.

Putusan MK yang menolak judicial review Undang-Undang Keuangan Negara tersebut, dikhawatirkan akan menimbulkan keresahan bagi BUMN. Bisnis yang dijalankan oleh BUMN akan terhambat karena adanya kekhawatiran apabila BUMN mengalami kerugian, dianggap merugikan keuangan negara. Dengan adanya perbedaan pandangan dan pendapat antara MA dan MK tersebut, tentu akan membingungkan praktik penegakan hukum oleh para penegak hukum terhadap BUMN, bahkan menimbulkan adanya ketidakpastian hukum. Padahal MA sudah berusaha konsisten di dalam memberikan putusan pada BUMN sebagai badan hukum yang mandiri seperti putusan terakhir yang diberikan terhadap PT Istaka Karya sebagai BUMN persero.

Upaya yang telah diperjuangkan oleh para akademisi dan didukung oleh MA sebagaimana dikemukakan di atas harus menelan rasa kecewa, karena para akademisi telah bersusah payah untuk menegaskan kembali asas dan doktrin hukum bahwa BUMN harus diperlakukan sebagai badan hukum yang memiliki kekayaan terpisah dari Keuangan Negara menjadi kandas karena adanya Putusan MK Nomor 48/PUU-XI/2013. Akibat dari Putusan MK berlaku bagi semua perkara yang terjadi di kemudian hari (erga omnes). Jadi ketika peraturan perundangundangan dinyatakan tidak sah oleh MK karena bertentangan dengan Undang-Undang Dasar atau peraturan perundang-undangan lain yang lebih tinggi, maka menjadi batal dan tidak sah untuk setiap orang.

\section{SIMPULAN DAN SARAN}

\section{A. Simpulan}

Berdasarkan analisis terhadap rumusan masalah dalam uraian sebelumnya, maka penulis menyimpulkan bahwa regulasi hukum nasional belum memberikan peluang bisnis bagi BUMN dalam era keterbukaan Masyarakat Ekonomi ASEAN, karena pertentangan dua pandangan terhadap Keuangan Negara yang diikutsertakan pada BUMN atau dalam penyertaan pada BUMN yang berasal dari APBN masih dipertahankan seperti keadaan semula. Namun dengan adanya Putusan Mahkamah Konstitusi (MK) Nomor 48/PUU-XI/2013 yang mempertahankan pemikiran bahan Keuangan Negara yang disertakan pada modal BUMN masih dianggap bagian dari Keuangan Negara, bahkan dengan Putusan MK ini memiliki dampak yang luas bagi semua perkara yang terjadi di kemudian hari karena Putusan MK yang bersifat erga omnes.

\section{B. Saran}

Berdasarkan simpulan di atas, maka penulis menyarankan seharusnya dalam menyongsong era keterbukaan Masyarakat Ekonomi ASEAN disiapkan regulasi yang dapat mendukung peluang bisnis bagi BUMN yang dapat menciptakan keleluasan bagi BUMN melakukan bisnis sesuai prinsip-prinsip Business Judgment Rule (BJR), sehingga perlindungan hukum bagi direktur dan jajarannya dari pertanggung 
jawaban atas setiap kebijakan, keputusan bisnis atau transaksi yang mengakibatkan kerugian bagi perusahaan, tetap terlindungi selama kebijakan, keputusan bisnis atau transaksi bisnis tersebut dilakukan dengan itikad baik, penuh kehati-hatian, kejujuran sejalan dengan tanggung jawab dan wewenangnya.

\section{DAFTAR PUSTAKA}

\section{Buku}

Direktorat Jenderal Kerja Sama Perdagangan Internasional, Kementerian Perdagangan Republik Indonesia, 2015, Menjadi Juara di Era MEA 2015.

Faisal Salam, Moch., 2005, Pemberdayaan BUMN Di Indonesia, Bandung, Pustaka.

Ibrahim R, 1997, Prospek BUMN dan Kepentingan Umum, Bandung, PT Citra Aditya Bakti.

Kusumaatmadja, Mochtar, 2000, Pengantar Ilmu Hukum, Buku I, Bandung, PT Alumni.

Muhammad, Abdulkadir, 2010, Hukum Perusahaan Indonesia, Bandung, PT Citra Aditya Bakti.

Ridhwan, M., et.al, 2015, Analisis Daya Saing dan Strategi Industri Nasional di Era Masyarakat Ekonomi ASEAN dan Perdagangan Bebas, Jakarta, Bank Indonesia.

Soekanto, Soerjono dan Mamudji, Sri, 2003, Penelitian Hukum Normatif Suatu Tinjauan Singkat, Jakarta, Rajagrafindo Persada.

Sumantri, Dibyo, 2004, Perjalanan Panjang Berliku: Perjalanan BUMN 1993-2003, Jakarta, Media Presindo

\section{Jurnal}

Mandala, Subianta, 2017, "UPICC Sebagai Model Bagi Pembaruan Hukum Kontrak Indonesia dalam Rangka Masyarakat Ekonomi ASEAN", Jurnal Media Hukum, Vol.24 No.2.
Sastrawidjaja, Man S., 2005, "Kedudukan Unpad Sebagai Badan Hukum Publik”, Jurnal Penegakan Hukum, Bandung, Januari,.

Sumiyati, Yeti, 2013, "Peranan BUMN dalam Pelaksanaan Tanggung Jawab Sosial Perusahaan untuk Meningkatkan Kesejahteraan Rakyat", Jurnal Hukum IUS QUIA IUSTUM, Vol. 20, No. 3.

Suprantio, Steven, 2014, "Daya Ikat Putusan Mahkamah Konstitusi Tentang Testimonium de Auditu”, Jurnal Yudisial, Vol. 7 No. 1

\section{Makalah}

Pramono, Nindyo, "Kedudukan Kekayaan PT (Persero) dalam Rezim UU No. 17 Tahun 2003 tentang Keuangan Negara Sebuah Pemikiran dari Sisi Hukum Bisnis”, Makalah, Magister Hukum Bisnis UGM.

\section{Website}

Barratut Taqqiyqh, "Di ASEAN, posisi Indonesia di level menengah-bawah", https:// lipsus.kontan. co.id/v2/mea/read/281/di-asean-posisiindonesia-di-level-menengah-bawah, diunduh senin 4 Juni 2018 pkl.6.40 WIB.

http://www.hukumonline.com/berita/baca/lt4cbc1b cd43fa9/pengadilan-boleh-sita-harta-bumn, diunduh pada 7 November 2016 Pukul 20.57.

http://www.kemenkeu.go.id/SP/mk-tolakpermohonan-uji-materi-atas-undang-undangkeuangan-negara-dalam-perkara-no-48puu-xi2013 diunduh pada 4 Juni 2016 Pukul 21.57.

http://sumbar.antaranews.com/berita/58502/bpkbumn-harus-tetap-bagian-keuangan-negara.html diunduh pada 7 November 2016 Pukul 22.40.

http://www.hukumonline.com/berita/baca/lt4cbc1b cd43fa9/pengadilan-boleh-sita-harta-bumn diunduh pada 17 November 201 Pukul 20.04. 